\title{
RESILIENSI IBU YANG MEMILIKI ANAK DOWN SYNDROME DI SIDOARJO
}

\author{
Fiqqi Anggun Lestari, Lely Ika Mariyati \\ Fakultas Psikologi Universitas Muhammadiyah Sidoarjo
}

\begin{abstract}
The aim of this study was to describe the characteristics and resilience factors for mothers who have children experiencing Down Syndrome. That is factors that help mother finds the strength to face the problem. The method was a qualitative exploratory study using three subjects 30-45 years old mother who has a child with Down syndrome and has resilience. The determination of the subject used purposive sampling techniques and located in some places according to the agreement of subject and significant others. Data collection methods used were interviews equipped with general guidelines as well as the recording field. The results showed that each mother were different in terms of characteristics and resilience factors and differences in educational factors, economic and employment background. Factors that affected the subject resilience also have differences. Some of the factors supporting emerging resilience, the family support factor was the support obtained by the subject.
\end{abstract}

Keywords: Resilience, Mother with Child Down Syndrome, Down Syndrome

\begin{abstract}
ABSTRAK
Penelitian ini bertujuan untuk memberi gambaran karakteristik dan faktor-faktor resiliensi ibu yang memiliki anak Down Syndrome yaitufaktor-faktor yang membantu ibu menemukan sebuah kekuatan untuk menghadapi masalahnya.Metode penelitian ini adalah kualitatif eksploratif dengan menggunakan tiga orang subjek ibu berusia 3045 tahun yang memiliki anak down syndrome dan sudah beresiliensi. Penentuan subjek menggunakan teknik purposif sampel dan berlokasi di beberapa tempat sesuai kesepakatan dari subjek maupun significant others. Metode pengumpulan data yang digunakan adalah metode wawancara yang dilengkapi dengan pedoman umum serta pencatatan lapangan. Hasil penelitian menunjukkan bahwa masing-masing ibu berbeda dalam hal karakteristik dan faktor resiliensi serta memiliki perbedaan pada faktor pendidikan, ekonomi dan latar belakang pekerjaan. Faktor yang mempengaruhi subjek beresiliensi juga memiliki perbedaan. Beberapa faktor pendukung resiliensi yang muncul, faktor dukungan keluarga merupakan dukungan yang didapatkan oleh subjek.
\end{abstract}

Kata kunci : Resiliensi, Ibu dengan Anak Down Syndrome, Down Syndrome

\section{PENDAHULUAN}

Setiap orangtua menginginkan dan merasa bahagia ketika melihat anaknya berkembang dengan sempurna. Namun demikian sering terjadi dimana anak memperlihatkan masalah-maslah dalam perkembangannya sejak usia dini (Rachmayanti dan Zulkaida, 2007). Salah satu masalah dalam perkembangan anak adalah gangguan 
psikiatrik yang dikenal dengan istilah "anak berkebutuhan khusus" (special needs children), yaitu anak yang secara bermakna mengalami kelainan atau gangguan (fisik, mentalintelektual, sosial dan emosional) dalam proses pertumbuhan dan perkembangannya dibandingkan dengan anak-anak lain seusianya adalah mereka memerlukan pelayanan pendidikan khusus (Direktorat Pembinaan SLB : Hayden, 2004).

Sebagian besar anggota keluarga mengalami penyesuaian dalam pekerjaan mereka, yaitu mengurangi jam kerja, berganti pekerjaan atau berhenti dari pekerjaan. Beragam penyesuaian yang harus dilakukan seringkali memunculkan bermacam-macam gangguan dan stres bagi orangtua terutama ibu. Stres yang dialami ibu juga terkait dengan beratnya tanggung jawab perawatan dan pengasuhan anak. Reaksinya memang bervariasi. Beberapa ibu yang mengatasi kondisi tersebut secara realistis, menolak, mengasihani diri sendiri, bersikap ambivalen, merasa bersalah ataupun membentuk pola ketergantungan dengan si anak.

Ibu adalah orang yang kali pertama merasakan suatu tekanan karena ia merasa tidak berharga dan gagal melahirkan seorang anak yang ia lahirkan dengan keadaan normal. Ibu yang paling terpukul karena secara tidak langsung ia yang sangat dekat dengan sang janin saat mengandung sampai pada masa melahirkan. Hal ini dapat ditunjukkan dengan salah satu hasil wawancara dalam penelitian yang meneliti tentang Dinamika Resiliensi Orangtua Anak Autis (Muniroh,
2010). Berdasarkan hasil kutipan wawancara yang dilakukan oleh peneliti di atas, dapat diketahui bahwa ibu yang memiliki anak berkebutuhan khusus lebih rentan dan lebih mudah merasa kecewa, sedih dan malu karena ia merasa yang bertanggung jawab atas semua yang dialami oleh anaknya.

Perasaan-perasaan yang dialami seorang ibu yang memiliki anak berkebutuhan khusus terutama down syndrome sudah dapat dipastikan akan memiliki suatu pekerjaan tambahan bagi dirinya seperti intensif dalam perhatian terhadap perkembangan anaknya. Tidak hanya menambah pekerjaan tetapi juga memikirkan masa depan anaknya ketika sang anak sudah memasuki usia pernikahan.

Anak Berkebutuhan Khusus memiliki banyak jenis antara lain autisme, down syndrome, ADHD, Speach Delay, Cerebral Palsy, Tunadaksa, Tunagrahita dan masih banyak lagi jenisnya. Anak berkebutuhan khusus yang menjadi focus dalam penelitian ini adalah down syndrome. Pengertian dari down syndrome adalah satu kerusakan atau cacat fisik bawaan yang disertai keterbelakangan mental. Lidahnya tebal dan retak-retak atau terbelah, wajahnya datar ceper dan matanya miring (Chaplin, 1995).

Pengertian lain tentang down syndrome adalah salah satu tunagrahita. Down Syndrome merupakan kelainan kromosom. Kromosom ini terbentuk akibat kegagalan sepasang kromosom saling memisahkan diri saat terjadi pembelahan. Ciri-ciri down syndrome tampak nyata dilihat dari fisik 
penderita, misalnya tinggi badan relatif pendek, kepala mengecil, hidung yang datar menyerupai orang Mongolia. Biasanya lapisan kulit penderita tampak keriput meskipun usianya masih muda (Smart, 2010).

Down Syndrome merupakan masalah yang penting karena seringkali terjadi di berbagai belahan dunia, sebagaimana menurut catatan Indonesia Center for Biodiversity dan Biotechnology (ICBB) Bogor, di Indonesia terdapat lebih dari 300 ribu anak pengidapdown syndrome. Sedangkan angka kejadian penderita down syndrome di seluruh dunia diperkirakan mencapai 8 juta jiwa (Aryanto, 2008). Angka kejadian kelainan down syndromemencapai 1 dalam 1000 kelahiran. Amerika Serikat, setiap tahun lahir 3000 sampai 5000 anak dengan kelainan ini dan di Indonesia prevalensi lebih dari 300 ribu jiwa (Sobbrie, 2008 dalam http://id.scribd.com/doc/DownSyndrome).

Beberapa kasus terlihat bahwa umur wanita terbukti berpengaruh besar terhadap munculnya down syndrome pada bayi yang dilahirkannya. Kemungkinan wanita berumur 30 tahun melahirkan bayi dengan down syndrome adalah 1 dibanding 1000. Sedangkan jika usia kelahiran adalah 35 tahun, kemungkinannya adalah 1 dibanding 400. Hal ini menunjukkan bahwa angka kemungkinan munculdown syndrome makin tinggi sesuai usia ibu saat melahirkan (Elsa, 2003 dalam http://id.scribd.com/doc/DownSyndrome).

Sumber lain menyebutkan bahwa jumlah kasus down syndrome di Indonesia sekitar 300,000 kasus, dan merupakan $15 \%$ dari jumlah kasus down syndrome dunia. Angka yang signifikan untuk populasi Indonesia yang merupakan 3,7\% dari populasi dunia (http://id.scribd.com/doc/88032067/D own-Syndrome).

Banyak di antara orangtua yang memiliki anak "berbeda" terutama yang memiliki anak down syndrome merasa malu, kecewa dan putus asa serta pasrah tidak melakukan apapun yang terbaik untuk anaknya. Orangtua menerima semua keadaan ini sebagai takdir yang sudah digariskan Sang Maha Pencipta untuk kehidupan mereka dan anak mereka (Smart, 2010).

Orangtua dengan anak yang didiagnosa mengalami down syndrome dengan anak normal memiliki tanggung jawab yang berbeda. Mangunsong (dalam Budiarti, 2013), mengelompokkan empat jenis tanggung jawab orangtua dengan anak berkebutuhan khusus. Pertama, orangtua dengan anak berkebutuhan khusus mempunyai tanggung jawab sebagai pengambil keputusan karena orangtualah yang memutuskan alternatif mana yang akan ditempuh anaknya. Tanggung jawab kedua adalah sebagai orangtua yang perlu menyesuaikan diri dengan keadaan anaknya, sosialisasi anak dan sebagainya. Ketiga adalah sebagai guru dari anaknya bukanlah pendidik anak berkebutuhan khusus yang professional, mereka bisa berperan dalam memberikan beberapa pelatihan pada aspek-aspek tertentu sebatas kemampuan yang dimiliki orangtua.

Terakhir, ibu juga memiliki tanggung jawab sebagai 'advocate', 
yaitu sebagai pendukung dan pembela kepentingan anaknya yang berkebutuhan khusus. Hadirnya tanggung jawab yang lebih kompleks membuat orangtua anak berkebutuhan khusus mengalami masalah yang lebih besar daripada orangtua dengan anak normal, sehingga berpotensi menimbulkan stress pada orangtua (Budiarti, 2013).

Penelitian di wilayah Sidoarjo dilakukan karena tidak sedikit ibu yang memiliki anak berkebutuhan khusus yang salah satunya adalah mengidap down syndrome. Di Sidoarjo juga terdapat sekolahsekolah yang khusus untuk anak penyandang down syndrome. Kasus down syndrome saat ini memang menjadi sorotan karena berkembang cepat dibandingkan kasus anak berkebutuhan khusus lainnya.

Keluarga yang memiliki anak dengan diagnosa down syndrome akan melalui proses tertentu yang memungkinkan mereka untuk bertahan dan beradaptasi hingga mereka dapat menjadi sebuah keluarga yang resilien. Ada pula reaksi orangtua yang kecewa dan merasa bahwa anaknya berbeda dengan anak-anak yang lain. Resiliensi dapat diartikan untuk menggambarkan bagian positif dari perbedaan individual dalam dalam respons seseorang terhadap stres dan keadaan yang merugikan (adversity) lainnya, Smet (dalam Desmita 2011). Meskipun resiliensi merupakan kapasitas individual untuk bertahan dalam situasi yang stresfull, namun tidak berarti bahwa resiliensi merupakan suatu sifat (traits), melainkan lebih merupakan suatu proses (process).
Resiliensi terbentuk dari interaksi antara faktor-faktor resiko dengan faktor-faktor protektif menurut Windle (dalam Kalil, 2003). Faktor resiko adalah segala sesuatu yang berpotensi untuk menimbulkan persoalan atau kesulitan, sedangkan faktor protektif adalah hal-hal yang memperkuat individu atau keluarga dalam menghadapi faktor-faktor resiko. Adaptasi yang baik dan berhasil terhadap suatu permasalahan mencerminkan kuatnya pengaruh faktor protektif yang dimiliki.

Istilah resiliensi diintrodusir oleh Redl pada tahun 1969 dan digunakan untuk menggambarkan bagian postif dari perbedaan individual dalam respon seseorang terhadap stres dan keadaan yang merugikan (adversity) lainnya (Smet, dalam Desmita 2011).Resiliensi (daya lentur) merupakan sebuah istilah baru dalam khasanah psikologi, terutama psikologi perkembangan. Paradigma resiliensi didasari oleh pandangan kontemporer yang muncul dari lapangan psikiatri, psikologi dan sosiologi tentang anak, remaja dan orang dewasa sembuh dari kondisi stres, trauma dan resiko dalam kehidupan mereka. Sejumlah besar ahli psikologi menyadari betapa individu (anak-anak, remaja bahkan orang dewasa) yang hidup pada era modern sekarang ini semakin membutuhkan kemampuan resiliensi untuk menghadapi kondisi-kondisi yang berubah dengan cepat. Sejumlah ahli psikologi memandang perlu untuk menghadapi kondisi-kondisi yang tidak menyenangkan untuk membangun kekuatan individu dengan melakukan sebuah resiliensi. 
Resiliensi dianggap sebagai kekuatan dasar yang menjadi fondasi dari semua karakter positif dalam membangun kekuatan emosional dan pskologikal seseorang. Tanpa adanya resiliensi, tidak akan ada keberanian, ketekunan, tidak ada rasonalitas. Sejumlah riset yang telah dilakukan meyakinkan bahwa gaya berpikir seseorang sangat ditentukan oleh resiliensinya dan resiliensi juga menentukan keberhasilan seseorang dalam hidupnya (Desmita, 2005).

Keluarga yang memiliki anak Down Syndrome menimbulkan stressor yang tinggi terutama pada ibu karena telah menguras energi dan pikirannya. Apabila stressor tersebut tidak dapat diatasi maka dapat menyebabkan stres yang berkepanjangan atau biasa disebut distress. Distress tersebut memiliki beberapa kemungkinan yakni gangguan neurotik dan gangguan terkait stres. Berdasarkan PPDGJ-III F430 reaksi stres akan dilihat kaitan waktu kejadian yang jelas antara terjadinya pengalaman stressor luar biasa (fisik atau mental) dengan onset dari gejala. Adapun gejala-gejala tersebut adalah terdapat gambaran gejala campuran yang biasanya berubah-ubah, selain gejala permulaan berupa keadaan "terpaku" (daze). Semua hal berikut dapat terlihat seperti depresi, kecemasan, kemarahan, kecewa, overaktif dan penarikan diri (PPDGJ-III, 2003).

Perkembangan resiliensi diadaptasi dari pendapat Redl yang menyatakan bahwa resiliensi digunakan untuk menggambarkan bagian postif dari perbedaan individual dalam respon seseorang terhadap stres dan keadaan yang merugikan (Desmita, 2011). Ibu yang memiliki anak dengan gangguan down syndrome masuk dalam tahap inferior. Tahap inferior tersebut termasuk dalam psikologi individual Adler. Tema-tema pokok dari teori psikologi Adler adalah inferior fisik dan inferor psikologi. Inferioritas fisik adalah rasa tidak lengkap oleh adanya kekurangan dalam tubuh. Inferioritas Psikologi, yaitu perasaanperasaan inferioritas yang bersumber pada rasa tidak lengkap atau tidak sempurna dalam setiap bidang kehidupan, Adler (dalam Alwisol 2009). Perasaan inferioritas bukan suatu pertanda abnormalitas, melainkan justru penyebab dari segala bentuk penyempurnaan dalam kehidupan manusia. Inferioritas bagi Adler berarti perasaan lemah dan tidak terampil dalam menghadapi masalah yang harus diselesaikan. Perasaan inferior ada pada semua orang karena manusia hidup sebagai makhluk yang kecil dan lemah. Akan tetapi, perasaan inferor tersebut bisa diminimalisir dengan melakukan resiliensi atau bangkit dari keterpurukan dalam diri. Ibu yang memiliki anak down syndrome mengalami masa ini karena ada penolakan dari dirinya, bingung dan menarik diri dari sosial karena merasa malu memiliki anak dengan gangguan tersebut, akan tetapi seorang ibu dapat memotivasi diri dengan adanya faktor protektif yang mempengaruhinya. Faktor protektif yang mampu membuat seorang ibu dapat beresiliensi adalah munculnya faktor kemandirian, keaktifan mengakses informasi, dukungan keluarga besar, ikhlas dan sabar, memiliki keluarga yang mampu berkomunikasi, kebersamaan dalam keluarga serta 
tidak berseberangan dalam menyikapi sesuatu (dalam http://wiwinhendriani.com)

Selain faktor pendukung, seseorang mampu beresilien dengan menunjukkan suatu karakter penunjang proses resiliensi. Individu yang resilien menunjukkan karakteristik seperti memiliki inisiatif, insight, independen dalam bertindak, memiliki hubungan sosial yang baik, memiliki kreatifitas, mampu menunjukkan humor dan moralitasnya, Wolins (dalam Desmita 2011). Namun apabila karakteristik tersebut tidak semua terpenuhi, bukan berarti individu tersebut gagal dalam beresilien tetapi ada karakteristik lain yang menjadi pendukung.

Perkembangan resiliensi yang didasari atas sebuah dorongan untuk hidupnya menjadi kuat dan berhasil menyesuaikan diri dalam berhadapan dengan kondisi yang tidak menyenangkan serta dapat mengembangkan kreatifitas dan keterampilan berangkat dari sebuah teori perkembangan yang mencakup dalam kepribadian seseorang dan usaha seseorang untuk menjadi kuat dan bertahan.

\section{METODE PENELITIAN}

\begin{tabular}{lrr}
\multicolumn{2}{c}{ Penelitian ini } & menggunakan \\
metode & kualitatif & deskriptif. \\
Penelitian & kualitatif & menurut
\end{tabular} Williams (dalam Moleong, 2011) adalah pengumpulan data pada suatu latar alamiah dengan menggunakan meteode alamiah dan dilakukan oleh orang atau peneliti yang tertarik secara alamiah. Sedangkan menurut Richie (dalam Moleong, 2011) adalah suatu upaya untuk menyajikan sosial dan perspektifnya di dalam dunia dari segi konsep, perilaku, persepsi maupun persoalan manusia yang akan diteliti.

Beberapa definisi yang dikemukakan oleh para ahli, maka (Moleong, 2011) menyatakan bahwa penelitian kualitatif adalah suatu penelitian ilmiah yang bermaksud untuk memahami fenomena tentang apa yang dialami oleh subjek penelitian misalnya perilaku, persepsi, tindakan dan lain-lain secara holistik dan dengan cara deskripsi dalam bentuk kata-kata dan bahasa pada suatu konteks khusus yang alamiah dengan memanfaatkan berbagai metode ilmiah. Makna deskriptif yang dimaksud adalah data yang dikumpulkan berupa kata-kata, gambar dan bukan angka-angka. Hal itu disebabkan oleh adanya penerapan metode kualitatif dan semua yang dikumpulkan kemungkinan menjadi kunci terhadap apa yang sudah diteliti kemudian laporan penelitian akan berisi kutipan-kutipan data untuk memberikan gambaran penyajian laporan tersebut.

Subjek dalam penelitian ini adalah orangtua yang dikhususkan pada ibu yang memiliki anak down syndrome usia anak-anak dan menggunakan teknik purposeful sampling yang berdasarkan kepada ciri-ciri yang dimiliki oleh subjek karena sesuai dengan tujuan penelitian yang akan dilakukan. Purposeful sampling yang merupakan teknik dalam non-probability sampling yang berdasarkan kepada ciri-ciri yang dimiliki oleh subjek yang dipilih karena ciri-ciri tersebut sesuai dengan tujuan penelitian yang akan dilakukan (Herdiansyah, 2010). 
Subjek yang dipilih adalah subjek yang memiliki kriteria:

1. Subjek terdiri dari tiga orang ibu yang memiliki anak down syndrome

2. Usia anak antara 3 sampai 15 tahun karena pada usia tersebut orangtua melalui proses yang tidak mudah dalam hal beresiliensi.

3. Usia ibu antara 30-45 tahun yang bisa menjadi faktor timbulnya gangguan gangguan down syndrome.

Selain mengemukakan ciri-ciri yang menjadi subjek penelitian, penggalian data juga melalui significant others, hal ini dilakukan agar dapat mendapatkan data tambahan tentang subjek dan hal-hal yang relevan dengan penelitian serta agar dapat mencocokkan data yang diperoleh dari subjek penelitian.

Teknik penggalian data menggunakan wawancara yang dilengkapi dengan pedoman umum wawancara. Pedoman umum wawancara digunakan untuk menjaga agar penggalian data tetap fokus pada permasalahan yang diungkap. Pedoman wawancara tersebut menyesuaikan keadaan di lapangan. Selain wawancara, teknik pengumpulan data dilengkapi dengan catatan lapangan. Catatan lapangan berisi deskripsi tentang hal yang diamati peneliti yang dianggap penting. Catatan lapangan harus bersifat deskriptif, pencatuman tanggal dan waktu dan dicatat dengan menyertakan informasi-informasi dasar seperti keterangan tempat, interaksi sosial dan aktifitas yang berlangsung dan lain-lain (Poerwandari, 2009).

\section{HASIL DAN PEMBAHASAN}

Masing-masing subjek menunjukkan karakteristik, bentuk dan faktor resiliensinya. Ketiga subjek memiliki suatu daya tahan dalam menghadapi berbagai macam konflik yang akan mereka terima dengan kehadiran seorang anak yang mengidap down syndrome. 
Tabel 1.

Matriks Profil Subjek

\begin{tabular}{|c|c|c|c|}
\hline Hasil Data & Subjek I (KM) & Subjek II (HR) & Subjek III (N) \\
\hline $\begin{array}{l}\text { Latar } \\
\text { Belakang } \\
\text { Pendidikan }\end{array}$ & $\begin{array}{l}\text { S1 dan pernah } \\
\text { mengajar di sekolah } \\
\text { TK }\end{array}$ & S1 & SMP \\
\hline $\begin{array}{l}\text { Latar } \\
\text { Belakang } \\
\text { Ekonomi }\end{array}$ & $\begin{array}{l}\text { Termasuk dalam } \\
\text { golongan menengah; } \\
\text { - Rumah sederhana } \\
\text { dengan kepemilikan } \\
\text { sendiri } \\
\text { - Memiliki kendaraan } \\
\text { roda empat } \\
\text { sederhana } \\
\text { - Pendapatan cukup } \\
\text { dengan 1 } \\
\text { tanggungan anak }\end{array}$ & $\begin{array}{l}\text { Termasuk golongan } \\
\text { menengah ke atas; } \\
\text { - Rumah cukup } \\
\text { mewah dan } \\
\text { kepemilikan } \\
\text { sendiri } \\
\text { - Memiliki } \\
\text { kendaraan roda } \\
\text { empat sederhana } \\
\text { - Pendapatan } \\
\text { cukup dengan } 3 \\
\text { tanggungan anak }\end{array}$ & $\begin{array}{l}\text { Termasuk dalam } \\
\text { golongan menengah } \\
\text { kebawah; } \\
\text { - Rumah masih Kontrak } \\
\text { - Pendapatan minim } \\
\text { dengan dengan } 3 \\
\text { tanggungan anak } \\
\text { - Kendaraan yang } \\
\text { dimiliki roda dua } \\
\text { bermesin (motor) }\end{array}$ \\
\hline Hasil Data & Subjek I (KM) & Subjek II (HR) & Subjek III (N) \\
\hline $\begin{array}{l}\text { Latar } \\
\text { Belakang } \\
\text { Pekerjaan }\end{array}$ & $\begin{array}{l}\text { Pernah mengajar di } \\
\text { sekolah TK namun } \\
\text { tidak berlangsung } \\
\text { lama. Saat ini KM } \\
\text { berjualan di stand } \\
\text { makanan. } \\
\text { Suaminya bekerja } \\
\text { sebagai guru. }\end{array}$ & $\begin{array}{l}\text { Menjadi guru di } \\
\text { sekolah TK yang } \\
\text { didirikannya. } \\
\text { Suaminya bekerja di } \\
\text { perusahaan swasta. }\end{array}$ & $\begin{array}{l}\text { Ibu rumah tangga. } \\
\text { Kadang membantu } \\
\text { membuat masakan di } \\
\text { catering. } \\
\text { Suaminya bekerja di } \\
\text { bidang jasa (sopir). }\end{array}$ \\
\hline $\begin{array}{l}\text { Riwayat } \\
\text { Kasus }\end{array}$ & $\begin{array}{l}\text { KM memiliki seorang } \\
\text { putra usia } 4 \text { tahun, } \\
\text { divonis DS ringan. } \\
\text { Km melakukan } \\
\text { berbagai usaha untuk } \\
\text { pengobatan anaknya. }\end{array}$ & $\begin{array}{l}\text { HR memiliki dua } \\
\text { orang putra dan satu } \\
\text { orang putri, usia } 9 \\
\text { tahun, divonis DS } \\
\text { ringan. HR } \\
\text { melakukan usaha } \\
\text { untuk mengobatkan } \\
\text { putrinya serta } \\
\text { mencari tempat } \\
\text { terapi. }\end{array}$ & $\begin{array}{l}\mathrm{N} \text { memiliki dua orang } \\
\text { putri dan satu orang putra. } \\
\text { Putri ketiga menderita DS } \\
\text { cenderung RM. N } \\
\text { mengetahui putrinya } \\
\text { menderita DS saat berusia } \\
\text { tujuh bulan. }\end{array}$ \\
\hline
\end{tabular}


Tabel 2.

Matriks Karakteristik Resiliensi Subjek

\begin{tabular}{|c|c|c|c|}
\hline Karakter & Subjek I (KM) & Subjek II (HR) & Subjek III (N) \\
\hline Inisiatif & $\begin{array}{l}\text { Subjek melakukan } \\
\text { pengobatan untuk } \\
\text { anaknya. Selain itu, } \\
\text { subjek mencari } \\
\text { tempat terapi dan } \\
\text { melakukan aktifitas } \\
\text { di luar terapi. }\end{array}$ & $\begin{array}{l}\text { Subjek berusaha } \\
\text { melakukan pengobatan } \\
\text { untuk anaknya dan mencari } \\
\text { tempat terapi yang cocok. } \\
\text { Selain itu, subjek memiliki } \\
\text { keinginan kedepan agar } \\
\text { dapat mandiri. }\end{array}$ & $\begin{array}{l}\text { Subjek } \\
\text { menyekolahkan } \\
\text { anaknya. Subjek juga } \\
\text { memiliki keinginan } \\
\text { ke depannya. }\end{array}$ \\
\hline $\begin{array}{l}\text { Insight / } \\
\text { wawasan }\end{array}$ & $\begin{array}{l}\text { Subjek paham akan } \\
\text { perkembangan } \\
\text { anaknya. }\end{array}$ & $\begin{array}{l}\text { Subjek sadar akan kondisi } \\
\text { anak dan menurutnya usia } \\
\text { orangtua tidak berpengaruh } \\
\text { pada lahirnya anak dengan } \\
\text { kondisi DS. }\end{array}$ & $\begin{array}{l}\text { Subjek mampu } \\
\text { menerima keadaan } \\
\text { anaknya dan tidak } \\
\text { menganggap usia } \\
\text { yang menjadi faktor } \\
\text { anak DS. }\end{array}$ \\
\hline Independen & $\begin{array}{l}\text { Subjek dapat } \\
\text { mengatasi perkataan } \\
\text { negatif dari } \\
\text { masyarakat yang } \\
\text { belum mengetahui } \\
\text { kondisi anaknya. }\end{array}$ & $\begin{array}{l}\text { Subjek dapat } \\
\text { memperlihatkan pada } \\
\text { masyarakat bahwa anaknya } \\
\text { tidak mengalami } \\
\text { kemunduran yang parah. }\end{array}$ & $\begin{array}{l}\text { Subjek mampu } \\
\text { mengatasi masalah } \\
\text { perihal anaknya, } \\
\text { walaupun .cenderung } \\
\text { malu-malu saat ada } \\
\text { pertanyaan orang lain } \\
\text { perihal anaknya }\end{array}$ \\
\hline Hubungan & $\begin{array}{l}\text { Subjek tidak begitu } \\
\text { akrab dengan tetanga } \\
\text { karena belum lama } \\
\text { menempati rumah } \\
\text { tersebut dan karena } \\
\text { kesibukan di luar } \\
\text { rumah (berjualan). }\end{array}$ & $\begin{array}{l}\text { Subjek termasuk orang } \\
\text { yang mudah bergaul dan } \\
\text { rutin mengikuti kegiatan di } \\
\text { lingkungan. }\end{array}$ & $\begin{array}{l}\text { Subjek cukup aktif } \\
\text { dalam kegiatan } \\
\text { dilingkungannya. }\end{array}$ \\
\hline Humor & $\begin{array}{l}\text { Subjek tidak begitu } \\
\text { menyukai humor. }\end{array}$ & $\begin{array}{l}\text { Subjek suka humor tapi } \\
\text { tidak terlalu. }\end{array}$ & $\begin{array}{l}\text { Saat sedang } \\
\text { berkumpul dengan } \\
\text { keluarga, subjek } \\
\text { sering bercanda }\end{array}$ \\
\hline Kreatifitas & $\begin{array}{l}\text { Subjek dapat } \\
\text { menciptakan } \\
\text { permainan untuk } \\
\text { anak dan biasa } \\
\text { membacakan } \\
\text { dongeng. }\end{array}$ & $\begin{array}{l}\text { Subjek mudah untuk } \\
\text { membuat sang anak } \\
\text { terhibur, selain itu juga } \\
\text { subjek gemar mengarang } \\
\text { dongeng untuk anak. } \\
\text { Subjek dan suami memberi } \\
\text { pengajaran sendiri untuk } \\
\text { sang anak }\end{array}$ & $\begin{array}{l}\text { Subjek mengajarkan } \\
\text { hal-hal kecil pada } \\
\text { anak. }\end{array}$ \\
\hline Moralitas & $\begin{array}{l}\text { Subjek mengajarkan } \\
\text { aturan yang mudah } \\
\text { untuk anak. }\end{array}$ & $\begin{array}{l}\text { Subjek mengajarkan } \\
\text { kebiasaan sehari-hari untuk } \\
\text { anak dan membantu } \\
\text { tetangga. }\end{array}$ & $\begin{array}{l}\text { Subjek bersedia } \\
\text { membantu sesama. }\end{array}$ \\
\hline
\end{tabular}


Tabel 3.

Matriks Faktor Yang Mempengaruhi Resiliensi Subjek

\begin{tabular}{|c|c|c|c|}
\hline Faktor & Subjek I (KM) & Subjek II (HR) & Subjek III (N) \\
\hline Kemandirian & $\begin{array}{l}\text { Subjek mampu } \\
\text { menanggapi perkataan } \\
\text { negatif orang yang } \\
\text { baru dikenal ketika di } \\
\text { tempat umum. }\end{array}$ & $\begin{array}{l}\text { Subjek dapat mengatasi } \\
\text { masalah yang berkaitan } \\
\text { dengan sang anak, } \\
\text { misalnya ada orang } \\
\text { yang berkata negatif. }\end{array}$ & $\begin{array}{l}\text { Subjek mampu } \\
\text { mengatasi masalah } \\
\text { yang dianggap baru. }\end{array}$ \\
\hline Sabar dan Ikhlas & $\begin{array}{l}\text { Subjek ikhlas dan } \\
\text { dapat mengambil } \\
\text { hikmah. }\end{array}$ & $\begin{array}{l}\text { Subjek ikhlas dan } \\
\text { menerima keadaan } \\
\text { anaknya. }\end{array}$ & $\begin{array}{l}\text { Subjek menerima } \\
\text { keadaan. }\end{array}$ \\
\hline Gigih dalam Usaha & $\begin{array}{l}\text { Subjek membuka } \\
\text { usaha menjual } \\
\text { makanan demi anak } \\
\text { serta berjuang dengan } \\
\text { memasukkan anaknya } \\
\text { ke tempat terapi. }\end{array}$ & $\begin{array}{l}\text { Subjek memasukkan } \\
\text { anak ke terapi serta } \\
\text { mendirikan sekolah agar } \\
\text { anaknya dapat } \\
\text { bersosialisasi. }\end{array}$ & $\begin{array}{l}\text { Subjek berusaha } \\
\text { agar anaknya bisa } \\
\text { mandiri. }\end{array}$ \\
\hline Keluarga Komunikatif & $\begin{array}{c}\text { Komunikasi } \\
\text { cenderung minim } \\
\text { minimal hanya lewat } \\
\text { telepon sesekali karena } \\
\text { suami bekerja diluar } \\
\text { kota }\end{array}$ & $\begin{array}{l}\text { Subjek dan suami saling } \\
\text { berkomunikasi hampir } \\
\text { setiap hati tentang } \\
\text { permasalahan keluaraga. }\end{array}$ & $\begin{array}{c}\text { Komunikasi } \\
\text { cenderung minim } \\
\text { minimal hanya lewat } \\
\text { telepon sesekali } \\
\text { karena suami bekerja } \\
\text { diluar kota }\end{array}$ \\
\hline $\begin{array}{l}\text { Kebersamaan \& } \\
\text { Dukungan Keluarga }\end{array}$ & $\begin{array}{l}\text { Suami jarang pulang } \\
\text { karena harus bekerja } \\
\text { diluar kota sehingga } \\
\text { sehingga kebersaam } \\
\text { sangat minim namun } \\
\text { sesekali rekreasi } \\
\text { bersama }\end{array}$ & $\begin{array}{l}\text { Subjek dan suami } \\
\text { menyempatkan waktu } \\
\text { untuk berkumpul hampir } \\
\text { setiap hari dan sesekali } \\
\text { rekreasi bersama }\end{array}$ & $\begin{array}{c}\text { Suami jarang pulang } \\
\text { karena harus bekerja } \\
\text { diluar kota sehingga } \\
\text { sehingga kebersaam } \\
\text { sangat minim namun } \\
\text { sesekali rekreasi } \\
\text { bersama }\end{array}$ \\
\hline $\begin{array}{l}\text { Dukungan Keluarga } \\
\text { Besar }\end{array}$ & $\begin{array}{l}\text { Subjek mendapat } \\
\text { dukungan dari } \\
\text { keluarga besar. }\end{array}$ & $\begin{array}{l}\text { Subjek mendapat } \\
\text { dukungan dari keluarga } \\
\text { besarnya dan keluarga } \\
\text { besar pihak suami. }\end{array}$ & $\begin{array}{l}\text { Subjek mendapat } \\
\text { dukungan dari } \\
\text { keluarga besar. }\end{array}$ \\
\hline $\begin{array}{l}\text { Keaktifan Mengakses } \\
\text { Info }\end{array}$ & $\begin{array}{l}\text { Browsing internet } \\
\text { untuk mencari tahu } \\
\text { perkembangan } \\
\text { anaknya. }\end{array}$ & $\begin{array}{l}\text { Subjek mencari info } \\
\text { tentang DS melalui } \\
\text { internet dan membaca } \\
\text { buku. }\end{array}$ & $\begin{array}{c}\text { Subyek hanya } \\
\text { menunggu } \\
\text { mendapatkan } \\
\text { informasin ttd DS } \\
\text { sesekali bertanya } \\
\text { dari tetangga, } \\
\text { keluarga dan terapis }\end{array}$ \\
\hline $\begin{array}{l}\text { Orangtua Yang Tidak } \\
\text { Berseberangan } \\
\text { Menyikapi Sesuatu }\end{array}$ & $\begin{array}{l}\text { Subjek dan suami } \\
\text { saling membantu } \\
\text { untuk perkembangan } \\
\text { anak. }\end{array}$ & $\begin{array}{c}\text { Subjek dan suami saling } \\
\text { membantu untuk } \\
\text { perkembangan anak. }\end{array}$ & $\begin{array}{l}\text { Subjek dan suami } \\
\text { saling membantu } \\
\text { untuk perkembangan } \\
\text { anak. }\end{array}$ \\
\hline
\end{tabular}


Tabel 4.

Matriks Dinamika Yang Muncul Pada Diri Subjek

\begin{tabular}{llll}
\hline \multicolumn{1}{c}{ Hasil } & \multicolumn{1}{c}{ Subjek I (KM) } & \multicolumn{1}{c}{ Subjek II (HR) } & \multicolumn{1}{c}{ Subjek III (N) } \\
\hline Dinamika & Awal mengetahui & Subjek merasa shock & Subjek terkejut \\
yang & sang anak divonis & setelah mengetahui bahwa & meilhat \\
Muncul & menderita down & anak yang dilahirkannya & keterlambatan \\
& syndrome, subjek & mengalami down & perkembangan \\
& merasa terguncang & syndrome. Walaupun kurang & yang dialami \\
& (kaget). Subjek & nyaman dengan perkataan & sang anak. Ada \\
& masih menyimpan & maupun perilaku orang yang & rasa kecewa \\
& perasaan sensitif & baru ditemui atau ketika & tetapi ia sudah \\
& terhadap orang lain & berada di tempat umum, ia & mampu untuk \\
& yang berkata & mampu mengatasinya & bangkit dari \\
& negatif. Tetapi & karena adanya dukungan & masalah \\
& subjek masih & dari keluarga dan nilai & tersebut. \\
& memiliki nilai & keimanan pada dirinya. & \\
& spiritual. & & \\
\hline
\end{tabular}

Subjek memiliki inisiatif diri dengan cara memeriksakan sang buah hati ke rumah sakit maupun berusaha mencarikan terapi yang cocok untuk anak mereka. Subjek juga sudah mampu menatap masa depan dengan keadaan anak yang memiliki keterbatasan. Subjek juga menginginkan sang anak dapat menjadi anak yang mandiri. Individu yang memiliki inisiatif yakni individu yang melibatkan keinginan yang kuat untuk bertanggung jawab atas apa yang dihadapi (Wolins, dalam Desmita 2005).

Subjek memiliki wawasan atau kemampuan mental untuk bertanya pada diri sendiri. Hal ini bertujuan untuk memahami diri sendiri. Subjek sudah memahami kondisi anaknya dan menganggap bahwa usia ibu di atas 30 tahun dapat menyebabkan down syndrome. Mereka menampik semua itu dikarenakan yang terjadi pada subjek tidak demikian.
Seseorang dapat dikatakan mampu beresiliensi jika mampu menjauhkan diri dari keadaan yang tidak menyenangkan saat berada di lingkungan yang memungkinkan terjadinya hal tersebut. Apalagi seseorang dengan keadaan memiliki anak down syndrome. Subjek tidak menunjukkan hal tersebut. Subjek tidak malu untuk mengajak sang buah hati pergi ke tempat umum dan kegiatan sosial masyarakat. Subjek mampu menunjukkan pada sosial bahwa anak mereka mampu walau dengan keterbatasan yang dimiliki.

Seseorang yang resilien mampu menjalin hubungan dengan orang lain dan saling mendukung dengan lingkungannya. Subjek kesatu tidak begitu akrab dengan tetangga karena masih baru. Namun di tempat lain subjek (KM) mampu berinteraksi dengan orang baru. Subjek kedua bersedia membantu tetangga yang membutuhkan bantuan. Subjek ketiga memiliki hubungan sosial yang cukup 
bagus dan mudah bergaul. Mereka tidak sungkan untuk berbaur dengan lingkungan karena mereka sudah mampu bangkit dari suatu masalah.

Humor adalah kemampuan untuk melihat sisi terang dari kehidupan dan menemukan kebahagiaan dalam situasi apapun. Seseorang yang resilien menggunakan rasa humornya untuk memandang tantangan hidup dengan cara yang baru serta mampu mengungkapkan perasaan humornya.

Kreatifitas melibatkan memikirkan berbagai pilihan dan konsekuensi dalam hidup. Kreatifitas melibatkan daya imajinasi yang tinggi dan bisa digunakan untuk menghibur diri sendiri maupun orang lain. Memiliki anak yang mengidap down syndrome bukanlah perkara yang mudah, tetapi semua itu dapat diatasi dengan kreatifitas dari subjek yang mampu menciptakan hal-hal yang bersifat kreatifitas sehingga sang anak bisa terhibur. Salah satu kreatifitas yang ditunjukkan oleh subjek adalah mendongeng untuk anak.

Subjek dapat mengevaluasi berbagai hal dan mengajarkan normanorma maupun ajaran yang mudah untuk sang anak agar mereka tertib dengan peraturan walaupun dengan keterbatasan yang mereka punya. Resiliensi terbentuk dari interaksi antara faktor-faktor resiko dengan faktor-faktor protektif menurut Windle (dalam Kalil, 2003). Faktor resiko adalah segala sesuatu yang berpotensi untuk menimbulkan persoalan atau kesulitan, sedangkan faktor protektif adalah hal-hal yang memperkuat individu atau keluarga dalam menghadapi faktor-faktor resiko. Faktor protektif yang dimaksud, yakni kemandirian, kesabaran dan keikhlasan, gigih dalam berusaha, keluarga komunikatif, kebersamaan dan saling dukung keluarga, dukungan dari keluarga besar, aktif mengakses informasi dan sikap orangtua yang tidak berseberangan dalam menyikapi sesuatu.

Dalam hal kemandirian, subjek mampu mengatasi masalah yang dihadapi dan tentu saja berkaitan dengan anak. Subjek mampu menyelesaikannya dengan cara mampu menahan untuk tidak marah jika ada orang lain yang berkata negatif terhadap anaknya. Faktor keluarga komunikatif juga sangat mendukung suatu proses resiliensi seseorang. Subjek selalu mengkomunikasikan dengan suami. Berbeda dengan subjek kesatu dan ketiga yang jarang berkomunikasi dengan suami dikarenakan sang suami berada di luar kota.

Kebersamaan dan saling dukung dalam keluarga juga sangat diperlukan untuk proses resilien. Dukungan yang diberikan oleh orang terkasih memberikan makna tersendiri bagi seseorang yang sedang dalam proses bangkit dari sebuah keterpurukan. Memiliki anak down syndrome memang dipandang sebelah mata ioleh sekitarnya. Namun apabila ada dukungan dari keluarga, maka seseorang akan lebih kuat dan mampu bangkit untuk mengatasi masalahnya. Ketiga subjek mendapat dukungan penuh dari keluarganya. Bentuknya bermacam-macam. Faktor itu yang salah satunya menjadi sumber kekuatan bagi subjek.

Subjek yang kesatu dan kedua aktif mencari informasi seputar 
kondisi yang dialami oleh sang anak. Keduanya mencari informasi melalui media seperti internet, membaca buku dan mengikuti berbagai macam kegiatan yang berhubungan dengan sang anak. Berbeda halnya dengan subjek ketiga yang hanya berdiam diri di rumah dan menunggu info dari orang lain. Akan tetapi, mereka sudah melakukan banyak cara untuk kemajuan sang anak.

Menyelesaikan masalah tidak hanya dilakukan seorang diri (ibu) saja, melainkan peran bapak juga sangat diperlukan. Dalam menyelesaikan masalah seharusnya diselesaikan bersama dan saling mencari solusi agar tidak berseberangan dan tidak menimbulkan konflik.

Ketiga subjek memiliki bentukbentuk resiliensi yang bermacammacam. Subjek kesatu berbekal usaha dan doa serta dapat menerima keadaan dan tidak putus asa. Segala yang dilakukan atas dukungan dari lingkungan, keluarga dan dorongan dari diri sendiri. Subjek kedua berusaha untuk mencari infomasi yang berhubungan dengan down syndrome dan mampu menerima keadaan anaknya. Ketiga subjek memiliki nilai-nilai spiritual yang tertanam dalam dirinya sehingga mereka mampu bertahan dan menerima keadaan.

Kepribadian yang dimiliki subjek juga membantu proses resiliensinya. Ketiga subjek memiliki kepribadian ekstrovert. Menurut Jung (dalam Alwisol, 2009) pengertian kepribadian ekstrovert adalah mengarahkan pribadi ke pengalaman objektif, memusatkan perhatiannya ke dunia luar, cenderung berinteraksi dengan orang di sekitarnya, aktif dan ramah. Ketiga subjek sama-sama memiliki kepribadian ekstrovert dan mampu berhubungan dengan sosial meskipun karakter dalam bergaul sedikit berbeda.

Berdasarkan pembahasan di atas terdapat beberapa perbedaan antara subjek I, II dan III ketika menuju proses resilien. Untuk menuju proses resilien, tidak semua faktor terpenuhi karena adanya perbedaan dari ketiganya. Faktor pendidikan, kepribadian, ekonomi dan rentang waktu juga menimbulkan banyak perbedaan. Subjek yang berpendidikan kurang dan hanya sebagai ibu rumah tangga, inisiatif untuk mencari informasi cenderung lama. Selain itu, faktor ekonomi juga berpengaruh. Subjek yang ekonominya mapan, lebih cepat mencari cara untuk kemajuan anaknya, misalnya terapi dan sebagainya.

Subjek yang memiliki ekonomi menengah, agak sulit untuk melakukan hal tersebut. Berdasarkan pembahasan di atas, penemu dinamika dalam diri subjek pun memang ada dan proses resliensi terdapat sebuah dinamika atau perubahan dari subjek sebelum memiliki anak, setelah mengetahui anaknya mengidap down syndrome dan proses resiliensinya. Ibu yang memiliki anak down syndrome mengalami tahap terguncang, tahap reaksi, tahap adaptasi dan tahap orientasi (Gunarhadi, 2005). Ketiga subjek sudah mencapai tahap superior. Tahap yang mampu bertahan dan bangkit dari masalah yang dialaminya. Ketiga subjek sudah memiliki resiliensi yang baik dan 
tidak lepas dari dorongan diri sendiri dan dukungan dari orang terdekat.

Berdasarkan analisis data dan pembahasan, maka diperoleh kesimpulan bahwa tiga ibu yang menjadi subjek dalam penelitian ini resiliensi yang berbeda. Perbedaan tersebut dilihat dari latar belakang pendidikan, pekerjaan dan latar belakang ekonomi. Adapun faktorfaktor yang dapat mempengaruhi proses resiliensi subjek dalam penelitian ini adalah dukungan dari keluarga dan peran lingkungan sekitar yang telah memberi motivasi serta dorongan dari kepribadian subjek yang tidak ingin berlarut-larut dalam kesedihan maupun kekecewaan, menerima keadaan putra maupun putrinya.

Sebelum menjadi individu yang resilien, ketiga subjek pernah mengalami adanya sebuah dinamika dalam dirinya saat anaknya menderita down syndrome dan proses menuju resiliensi. Selain itu dapat disimpulkan dari ketiga subjek bahwa tidak ada penyuluhan atau sosialisasi mengenai down syndrome dari petugas kesehatan setempat.

\section{DAFTAR PUSTAKA}

Alwisol. 2009. Psikologi Kepribadian. Malang : UMM Press.

Chaplin, J. 1995. Kamus Lengkap Psikologi. Jakarta : PT.Raja Grafindo Persada.

Desmita. 2005. Psikologi Perkembangan. Bandung : PT. Remaja Rosda Karya.

Desmita. 2011. Psikologi Perkembangan Peserta Didik .
Bandung : PT Remaja Rosda Karya.

Down Syndrome diakses pada tanggal 3 Januari 2013 dari http://id.scribd.com/doc/880320 67/downsyndrome.

Faktor resiko dan faktor protektif resiliensi. 2011. (on line).

Diakses pada 3 Januari 2013 dari http:// wiwinhendriani.com/2011

Grotberg,E.1999.Tapping Your Inner Strength, Oakland, CA : New Harbinger Publication, Inc.

Gunarhadi. 2005. Penanganan Anak Sindroma Down Dalam Lingkungan Keluarga dan Sekolah. Jakarta : Depdiknas.

Herdiansyah, Haris. 2010. Metodologi Penelitian Kualitatif Untuk Ilmu-ilmu Sosial. Jakarta : Salemba Humanika.

Kalil, A. 2003. Family Resilience and Good Child Outcomes : A review of the literature, New Zealand centre for social research and evaluation ministry of social development.

Budiarti, Retna. 2013. Pengaruh Support Group Counseling Dalam Meningkatkan Self Awareness Orangtua yang Memiliki Anak Berkebutuhan Khusus. Jurnal Psikologia Vol. 2, No. 1, Hal 77- 86.

Maslim, Rusdi. Dr. 2001. Diagnosis Gangguan Jiwa Rujukan Ringkas dari PPDGJ III. Jakarta : PT. Nuh Jaya.

Moleong, J. Lexy. 2011. Metode Penelitian Kualitatif. Bandung : PT. Remaja Rosdakarya. 
Muniroh, Siti Mumun. 2010. Rachmayanti, S., Zulkaida, A., (2007) Dinamika Resiliensi Orangtua Yang Memiliki Anak Autis. Vol.7.No.2. Diakses pada 31 Oktober 2012.

Poerwandari, Kristi. 2009.

Pendekatan Kualitatif untuk Penelitian Perilaku Manusia. Lembaga Pengembangan Sarana Pengukuran dan Pendidikan Psikologi. Depok : Penerimaan Diri Orangtua Terhadap Anak Autis dan Peranannya dalam Terapi Autisme. Jurnal Psikologi.1 (1). 7-17.

Smart, Aqila. 2010. Anak Cacat Bukan Kiamat Metode Pembelajaran dan Terapi Untuk Anak Berkebutuhan Khusus. Yogyakarta : Kata Hati

Fakultas Psikologi Universitas Indonesia. 